\title{
対話ロボットの反応時間と反応遅延時における間投詞の効果
}

\author{
志和 敏 之*1*2 神田崇行*1 今 井倫 太*1*2 \\ 石黒浩 $* 1 * 3$ 萩 田紀 博*1 安 西 祐一郎*2
}

\section{How Quickly Should Communication Robots Respond?}

\author{
Toshiyuki Shiwa ${ }^{* 1 * 2}$, Takayuki Kanda*1, Michita Imai*1*2, \\ Hiroshi Ishiguro*1*3, Norihiro Hagita*1 and Yuichiro Anzai*2
}

\begin{abstract}
This paper reports a study about system response time (SRT) in communication robots that utilize human-like social features, such as anthropomorphic appearance and conversation in natural language. Our research purpose established a design guideline for SRT in communication robots. The first experiment observed user preferences toward different SRTs in interaction with a robot. In other existing user interfaces, faster response is usually preferred. In contrast, our experimental result indicated that user preference for SRT in a communication robot is highest at one second, and user preference ratings level off at two seconds. However, a robot cannot always respond in such a short time as one or two seconds. Thus, the important question is "What should a robot do if it cannot respond quickly enough?" The second experiment tested the effectiveness of a conversational filler: behavior to notify listeners that the robot is going to respond. We used the same strategy in a communication robot to shadow system response time. Our results indicated that using a conversational filler by the robot moderated the user's impression toward a long SRT. Put it all together, we obtained a) users' impressions toward the robot are unchanged until one second SRT, b) the robot should react within two seconds SRT, and c) use of conversational fillers are effective to let the users to wait from these two experiments.
\end{abstract}

Key Words: Communication Robots, System Response Time, Conversational Filler

\section{1.は じめに}

近年，コミュニケーションロボットに関する研究の発展によ り，人間と対話によってコミュニケーションをとることのできる 人間型ロボットが登場してきており，ロボットの博物館やショッ ピングモール等の公共の場での運用が期待されている.もし人 間に似た身体をもつロボットが, 人間同士の対話に遜色のない 形で対話できるのであれば，ユーザに人間同士のコミュニケー ションを想起させ，情報機器に詳しくないユーザにも容易に情 報提示ができると考えられる。 人間同士のコミュニケーション を参考にすることは，扱いやすいコミュニケーションロボットの インタラクションをデザインする上で重要なアプローチである. 本研究ではロボットの反応時間に焦点を当てる. 本研究の目

原稿受付 2008 年 4 月 20 日

${ }^{* 1}$ ATR 知能ロボティクス研究所

$* 2$ 慶應義塾大学大学院理工学研究科

$* 3$ 大阪大学大学院工学研究科

${ }^{* 1}$ ATR Intelligent Robotics and Communication Laboratories

${ }^{* 2}$ Graduate School of Science and Technology, Keio University

${ }^{* 3}$ Graduate School of Engineering, Osaka University

口本論文は学術性で評価されました。
的はコミュニケーションロボットの反応時間がユーザに与える 影響を測定し，コミュニケーションロボットの反応時間をデザイ ンするための指針を作ることである，具体的には，ユーザが許 容できるロボットの反応時間の範囲と, ロボットがユーザの許 容できる時間内に反応できない場合の対処に関する指針を，二 つの検証実験で得られた知見を基に述べる.

反応時間に関しては，従来ヒューマンコンピュータインタラ クション (HCI) の分野の研究で多く扱われている。それらの 研究から, システムの反応時間は短いものほどユーザに好まれ るという特徴 [1]〜 [3] が明らかになっており, また, 短い反応時 間は複雑なタスクにおいて，ユーザのミスの原因になる [4] とい う知見が得られている。 さらにユーザが許容するシステムの反 応時間の限界として，2秒ルールというものが広く知られてい る [5] [6]. 2 秒ルールとはシステムがユーザに対して反応する際, ユーザを 2 秒以上待たせてはいけないというものである.これ は, GUI や電話, テレビ, ウェアラブルコンピュータなど, 様々 なヒューマンインタフェースのデザインに広く使われている [7]. また, システムがユーザの許容できる時間内に反応できない場 合の対処法に関しても, ユーザの待つことに対する苛立ちをな だめるため様々な手法がある. 最も単純な例としては, パソコ 
ンのマウスのカーソルの砂時計がある.もしシステムがユーザ の要求したプロセスを短時間に終わらせることができない場合, カーソルを砂時計に変えて, 実行中であることをユーザに知ら せるのである．また，伊藤らは発話による自動応答システムに おいて, システムが動作中であるということや, 発話継続中の サインとして人間の場合同様にシステムが応答しょうとしてい ることをユーザに知らせることに，間投詞を用いることが有効 であることを明らかにした $[8]$. 間投詞は「あの」や「えっと」 等の言葉で, 人間同士の対話で相手の発話に対して使用された 場合, 反応するための時間稼ぎや，相手に自分が応答しようと していることを知らせる働きがある $[9]$.

ロボットの反応時間に関しては，ヒューマンロボットインタ ラクション (HRI) の分野の研究で扱われている。例えば，神 田らは人間同士のコミュニケーションから，ロボットが人間に 道案内をする場合, 自然に見せるためには 0.89 秒の間を空け る必要があることを見つけた $[10]$. 山本らは「こんにちは」等 の挨拶をロボットと人間が交わすとき，人間の挨拶に対してロ ボットは 0.3 秒の間を空けてから反応したほうがよいことを見 つけた [11]. しかしロボットの反応時間に焦点を当てている研 究はまだ少なく, 既存の研究はユーザに対するロボットの最適 な反応時間を見つけることに着目している.

このようにHRI の分野では，個別の反応時間の調査が行わ れているだけで，反応時間がコミュニケーションに与える影響 を網羅的に検証した研究は皆無である. 反応時間の違いによっ て生じる機器の印象の変化の重要性は, HCI の分野で詳細に検 証され，示されているのと同様に，HRIの分野でも重要な知見 である。ロボットがユーザの許容時間内に反応できない場合の 対処法として，HCI の研究であった間投詞を利用することが考 えられる。既存研究では，ロボットが反応しないことに対して ユーザが抱く印象悪化の抑制に間投詞の効果があるのか, また 効果があるとすればどの程度なのか, 間投詞の利用に関する具 体的なデザインの指針となるべきものは示されていない.

本研究では，上記の問題を解決するため，ロボットの反応時 間の許容範囲の特定と，その許容範囲内でロボットが反応でき なかった場合の間投詞のユーザの印象悪化の抑制に対する有用 性の検証を目的とする.

そこで，コミュニケーションロボットの反応時間に関する実 験を二つ取り扱った。最初の実験は短い反応時間に焦点を当て, どの程度の反応時間でユーザが悪い印象をもつかを調べ，ロボッ トの反応時間の許容範囲を調べた。また，ロボットの反応時間 のデザインの指針を得ることも目的としており，単純な GUI と 比較することで，HCI で培われた，2秒ルール等の反応時間の デザイン指針がロボットでも当てはまるかを検証した。二目 の実験ではロボットの反応時間を長くし， ロボットが許容範囲 内の反応時間で反応できない場合, 間投詞の使用によって待つ ことに対するユーザの印象悪化を抑制できるか，ユーザの待ち 時間に注目し，間投詞の効果を定量的に調へ，その有効性を検 証した (Fig. 1)。最後にこれらの実験から得られた知見を，ロ ボットの反応時間をデザインするための指標として提案した。

本稿の構成を簡単に述べる。 まず，第 2 章でロボットの反応 時間の許容範囲の検証とそのために行った実験について詳述し,

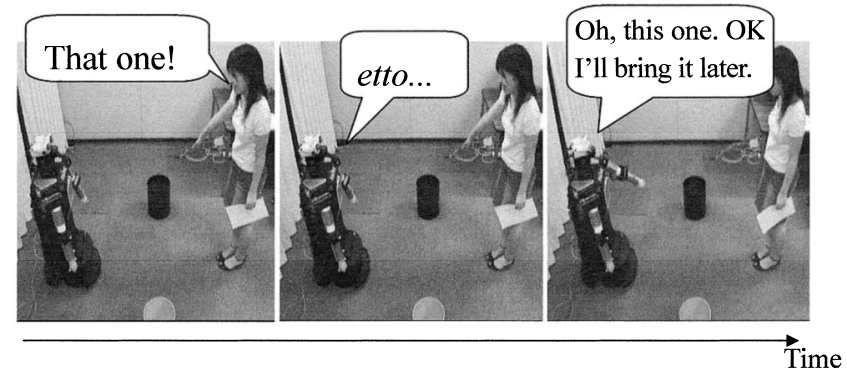

Fig. 1 Robot performs conversational fillers to buy time

次に第 3 章で間投詞によるユーザの印象悪化の抑制の検証とそ のために行った実験について詳述する。第 4 章では，これらの 検証で得られた知見と実験環境に関する考察を述べ，最後に第 5 章において, 結論を述べる。

\section{2.ロボットの反応時間の許容範囲の検証（実験 1 )}

この実験では，1〜 5 秒程度の短い時間間隔に焦点を当てロ ボットの反応時間を考える。この実験の目的は，ユーザが覀い 印象をもつ反応時間を見つけることにあるので，ロボットの反 応時間を変えることでユーザの印象がどのように変化するかを 調べる。また，単純な GUI の反応時間に関しても同様の実験 を行い，ロボットの反応時間との比較検討を行う。GUIにおけ る反応限界時間の 2 秒ルールと比較することで，人間とロボッ トとのインタラクションが従来提案されてきたヒューマンコン ピュータインタラクションとどう違うのか明らかにする.

\section{1 実験方法 被験者}

被験者として 38 名の大学生（男性：21 名, 女性：17 名, 平 均年齢：20.9）に参加してもらった.

\section{実験環境}

実験の夕スクは，対話によるロボットとのインタラクション と，マウスを用いた GUI 操作の 2 種類である。下記にそれぞ れのタスクの詳細を示す.

【Setting 1: ロボットとのインタラクション】

ユーザと対話を行うコミュニケーションロボットとして， Robovie を用いた [12]（Fig. 2). Robovie は高さが約 1.2 [m] のロボットで，人間に似た上半身をもっている.

実験中，被験者は Table 1 に示す簡単な 4 種類の対話をロ ボットと行う。ロボットとの対話を，発話形式の違い（社会的， 指示的）と動きの有無を組み合わせた $2 \times 2$ の 4 条件に分類し た。これら 4 種の発話はHRI で頻繁に用いられる対話の形を基 に作成した。まず，発話の社会的な形式というのは，相応しい使 用場面が社会的に決まっているものであり，挨拶や感謝の提示 が代表的な例である，相応しい使用場面が決まっているので，口 ボット側の反応も反射的に即座に生成されることが期待される と思われる。一方の指示的な形式は, 社会的な形式に比べて発話 の内容を理解し，それに相応しい反応をロボットが生成する必要 がある。したがって被験者もロボットが反応するまである程度の 時間がかかることを許容すると思われる. それぞれの発話形式 に対して被験者の動きの有無の影響を見るために，社会的な形 


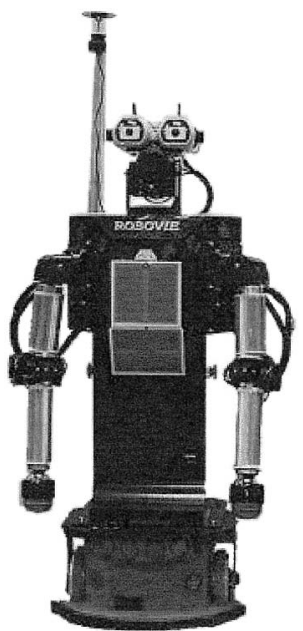

Fig. 2 Robovie

Table 1 Four types of user action

\begin{tabular}{|l|l|l|l|}
\hline \multicolumn{2}{|c|}{} & \multicolumn{2}{l|}{ Motion } \\
\cline { 3 - 5 } \multicolumn{2}{|c|}{} & With motion & Without motion \\
\hline \multirow{3}{*}{ Form } & Ritual & 1. Greeting & 4. Appreciation \\
\cline { 2 - 5 } & Instructional & 3. Deictic & 2. Request \\
\hline
\end{tabular}

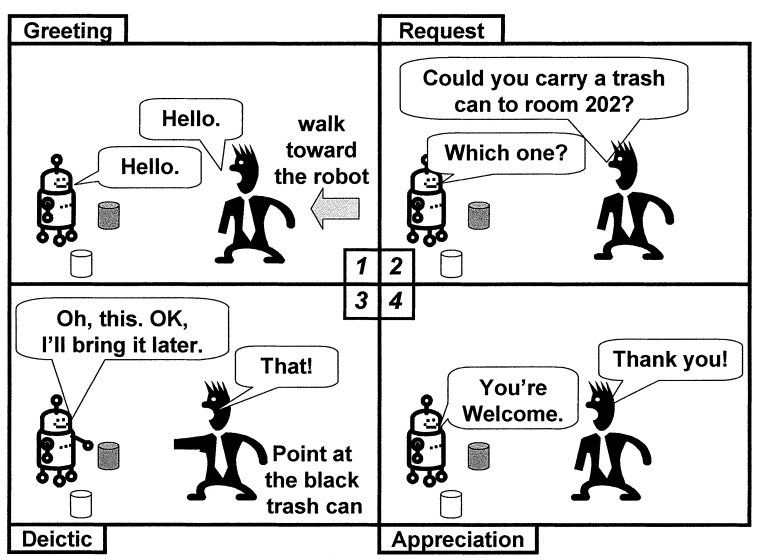

Fig. 3 Conversation between user and robot

式（Ritual form）の発話に対しては, 近付く／近付かないとい う動きの有無を付け，それぞれ，挨拶のため近寄る（Greeting）, その場で感謝の言葉を述べる (Appreciation), という発話例を 想定した。また指示的な形式 (Instructional form) には, 指差 しの有無をつけ，それぞれ，指差しを伴う指示 (Deictic)，指 差しを伴わない指示 (Request), とした. 以上の分類は, 発話 形式の違いおよび被験者の動きの有無が, 被験者の反応時間に 対する印象に影響を及ぼすのではないかという考えの元で行っ たものである.

実験で行った被験者とロボットの対話を Fig. 3 に示す．対話 は Table 1 の 4 種の発話を 1 回ずつ行うことで 1 セッションと した．実験の様子を Fig. 4 に示す。

ロボットの反応は Wizard of $\mathrm{Oz}$ 方式によってコントロール した。操作者は被験者の後ろに座り, 実験中は被験者の視界に

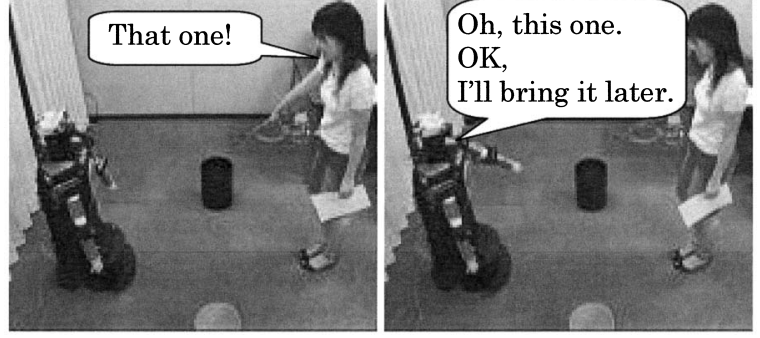

Fig. 4 Scenes of experiment (Deictic)

入らないようにした，操作者は被験者の発話が終わるのと同時 にボタンを押すことで，ユーザの 4 種の発話に対応したロボッ 卜の反応を生成する。ロボットの反応はボタンを押されると，あ らかじめ設定された反応時間に基づいて，その反応を実行する. 反応はロボットの発話とジェスチャにより構成されており, 発話 はあらかじめ生成した合成音声を再生することで実現した。被 験者に Fig. 3 に示したような決められた台詞を言わせることで, 被験者の発話の終わりとボタンを押すタイミングの同期を容易 にした，発話認識によるユーザの発話の終わりの検知は雑音等 に弱く, 精確な検知が難しいため, この Wizard of Oz 方式に よるロボットの反応の詳細な制御は必要であった。また，この 実験結果のうち, 237 個のデータをランダムに選択して分析し たところ, オペレータエラーは十分に小さかったことが確認で き $(M=0.108, S t d=0.1(N=237))$, この Wizard of $\mathrm{Oz}$ 方式はうまくいったと言える.

【Setting 2: GUI 操作】

GUI 操作のタスクを Fig. 5 に示す. GUI は, 四つのボタン で構成されており，押すと写真を表示する。被験者は備え付け られたマウスを使って，これら四つのボタンを順番に押してい くように教示された.

また, 被験者のバイアスによる評価の偏りを防ぐため, 反応 時間の長短は, システムが写真を表示するまでに, 表示するべス 卜な写真を選ぶために計算をしているためと説明しており，実 験の意図を隠した。ボタンが四つあるのは, ロボットとのイン タラクションの 1 セッションが会話四つで成り立っていること に合わせて，1 セッションにつき被験者に 4 回ボタンを押しても らうためである. 実験の様子を Fig. 6 に示す. 実験を通して, 同じ写真を被験者が見ることがないよう, 十分な数の写真を用 意した。

\section{実験条件}

本実験では，GUI の反応時間の制限として挙げられる 2 秒を 基準として，0， 1，2，3 秒という 4 種類の反応時間を用意し た.これらの反応時間の違いによって被験者のロボットおよび GUIに対する印象が異なるかを調べた.

\section{実験手順}

本実験は被験者内比較を行い，実験条件の順序によって，被 験者の印象に偏りがでる可能性を除外するため, 本実験では実 験条件とタスクの順番に対し，カウンタバランスをとった.

まずロボットとのインタラクションと GUI 操作のどちらを先 にするかを決め, それぞれの夕スクにおいて 4 種すべての反応 時間で実験が行われた。 


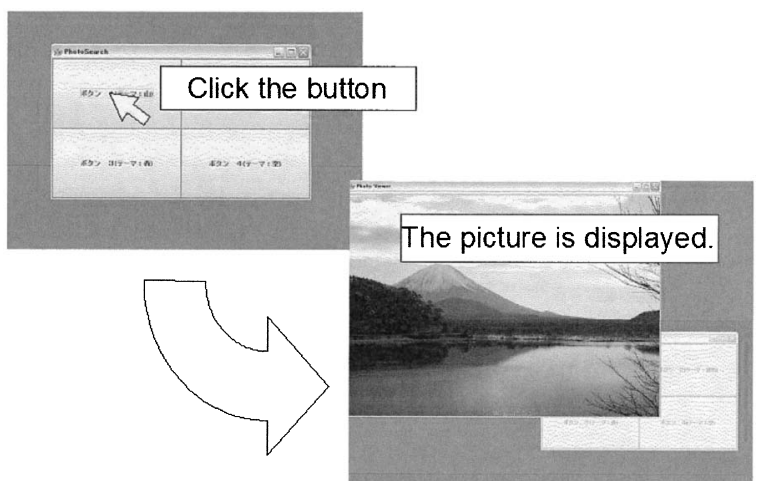

Fig. 5 GUI's four buttons

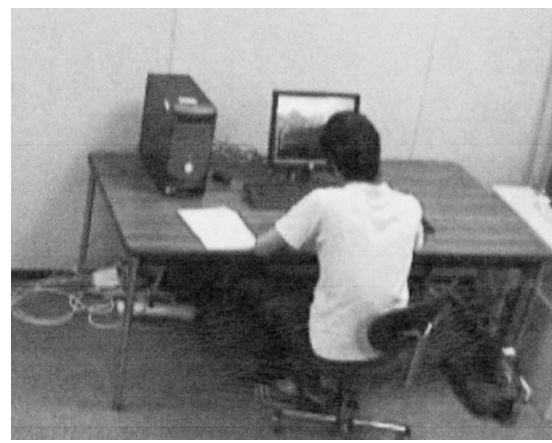

Fig. 6 Operation with GUI setting

実験前に被験者は，ロボットとのインタラクションの方法と, GUI の操作方法を教示される，それぞれの夕スクに打いて，被 験者は一つのセッションを 8 回ずつ繰り返すよう求められる. これは 4 種類の反応時間をそれぞれ 2 回ずつ行うためである. それぞれのタスクに関する詳しい手順は下記に示す。

(a) ロボットとのインタラクション

（1）被験者はロボットから $2[\mathrm{~m}]$ 離れたところに立つ.

（2）被験者はロボットに近づき，Fig. 3 に示した対話を行う. セッション中, 被験者はロボットが反応する度にその反応時間 に対する印象を測るアンケートに答える。

(b) GUI 操作

(3) マウスのついたパソコンのディスプレイの前に座る.

（4）マウウを使って,「ボタン $1 」$,「ボタン $2 」$,「ボタン $3 」$,「ボ タン 4」とそれぞれ書かれたボタン四つを順に押していく. それぞれのボタンを押すと写真が表示される。

セッション中, GUI が写真を表示する度にその反応時間に対す る印象を測るアンケートに答える。

\section{2 評価方法}

反応時間の評価には, ロボットの発話ごとに，その反応時間 が被験者にとってどうだったか，7段階（1が最も悪く， 7 が最 も良い)のリッカート尺度で評価してもらった。

評価：ロボットが反応するタイミングに対する被験者の好み （1. 非常に悪い 4. どちらでもない 7. 非常に良い)

\section{3 仮説と予測}

今までの HRI の研究で示唆されたように, GUI 等の HCI の

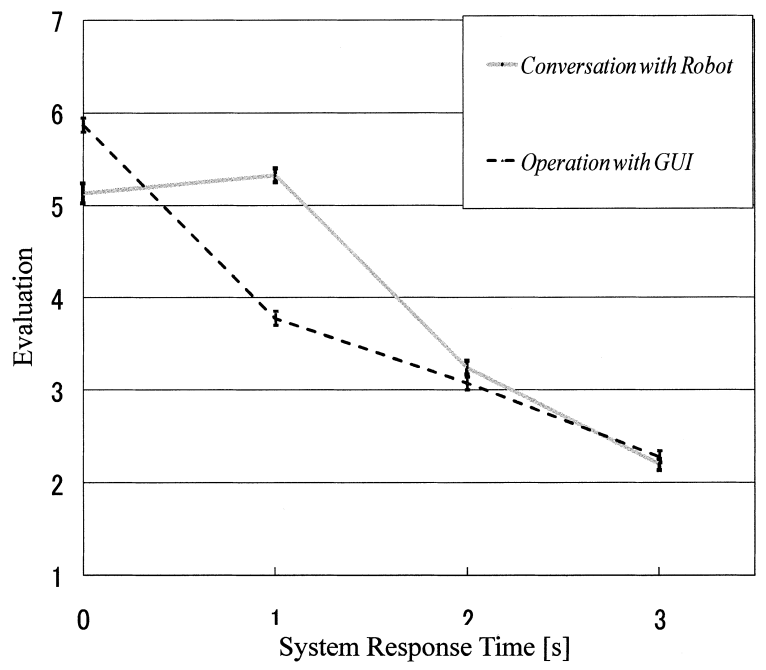

Fig. 7 Users' impressions of different SRTs

ときと違い，ユーザはすぐに反応されるより，少し間があってか ら反応される方を好むと思われる. また, 研究所内のメンバに よる予備実験で 1 秒の反応時間が自然な反応であると許容され ていたことと, 反応時間 2 秒に対する被験者の印象は反応時間 1 秒に比べても低かったことから，以下の二つの仮説を立てた.

（1）反応時間が 1 秒まではロボットの反応時間に対する被験者 の印象は下がらない.

(2) 2 秒ルールはロボットとのインタラクションにおいても有 効である。

また，この仮説に基づき，実駼結果に関して下記のような予 測を立てる。

（1）ロボットとのインタラクションでは, 被験者の反応時間に 関する印象評価は反応時間 0 秒と 1 秒ではほとんど変わら ない.

（2）GUI 操作に扔いては，被験者の反応時間に関する印象評価 は反応時間に対して単調減少する。

（3）どちらのタスクにおいても， 2 秒を超えると被験者の反応 時間に関する印象評価は悪くなる。

\section{4 実験結果}

反応時間に対するロボットとのインタラクションに扔りる被 験者の印象評価と GUI 操作に扔ける被験者の印象評価を Fig. 7 に示す。

\section{予測 1 に関する検証}

ロボットとのインタラクションの実験結果に関して反応時間 と 4 種の発話それぞれを要因とし， 2 要因の分散分析を行った. その結果，それぞれの要因間の交互作用はなく $(F(9,1163)=$ 1.490$, n.s. $)$, 反応時間 $(F(3,1163)=422.355, p<0.001)$ と 4 種の発話 $(F(3,1163)=4.519, p<0.005)$ それぞれの 要因に扔いて主効果があった。

反応時間の 4 要素に関して Bonferroni の多重比較検定を行っ たところ，すべての要素間に扔いて有意差が見られた（0 秒と 1 秒 $: p<0.005$, 他の要素間 $: p<0.001)$.このことから, 口 ボットとのインタラクション時の反応時間に対する印象評価は 


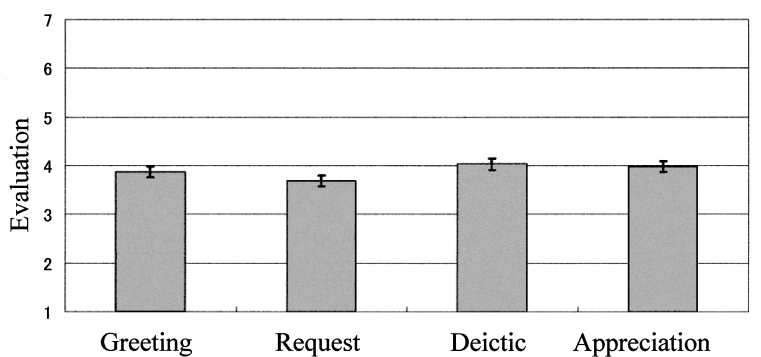

Fig. 8 Preference for SRT with four elements of interactions

単調減少せず， 1 秒時に最も高くなったことが確かめられた．

予測 2 に関する検証

GUI 操作の実験結果に関して反応時間と 4 種のボタンそれ ぞれを要因とし，2 要因の分散分析を行った。その結果，それ ぞれの要因間の交互作用はなく $(F(9,1163)=0.672$, n.s. $)$, 反応時間 $(F(3,1163)=709.303, p<0.001)$ と 4 種のボタ ン $(F(3,1163)=4.537, p<0.005)$ それぞれの要因におい て主効果があった。

反応時間の 4 要素に関して Bonferroni の多重比較検定を行っ たところ，すべての要素間において有意差が見られた（すべて の要素間において $p<0.001)$. このことから， GUI 操作時の 反応時間に対する印象評価は, 反応時間に対して単調減少して いることが確かめられた

\section{予測 3 に関する検証}

ロボットとのインタラクションと GUI 操作の両タスクにおけ る Bonferroni の多重比較検定から, それぞれの反応時間に対す る印象評価は反応時間の 4 要素すべての間に有意差があり, 被 験者の印象評価が悪化していることが確かめられた。

4 種の発話間の違いに関して

ロボットとのインタラクションにおける 4 種の発話ごとの被 験者の印象評価を Fig. 8 に示す. 予測 1 の検証において述べた とおり, 4 種の発話という要因に関して主効果があったことが 確認された.

Bonferroni の多重比較検定をこの 4 種の発話の各要素に関し て行ったところ, 要求と指差しの要素間 $(p<0.005)$ と, 要求 と感謝の要素間 $(p<0.05)$ において有意差がみられた。 しか しながら, これらの要素は対話の構成上, 順番が決まっており, 順序効果の影響がないとは言い切れない。また参考までに GUI 操作の 4 種のボタンの各要素に関して Bonferroni の多重比較 検定を行ったところ, 順序効果により, ボタン 1 とボタン 4 に 関してのみ有意差がみられた。このことから，4種の発話に対 する順序効果の影響を消すことができないため, 4 種の発話の 各要素間の違いに関して今回の実験から, なんらかの結論を引 き出すことはできなかった。

\section{3. 間投詞による印象悪化の抑制の検証（実験 2）}

実験 2 は, ロボットの反応時間が長かった場合に生じるロボッ トへの印象低下が，間投詞を用いることでどのように変化する かを調べることを目的としている. ロボットとのインタラクショ ンで, 反応時間を 3 秒から 9 秒に変化させた場合, 間投詞の有

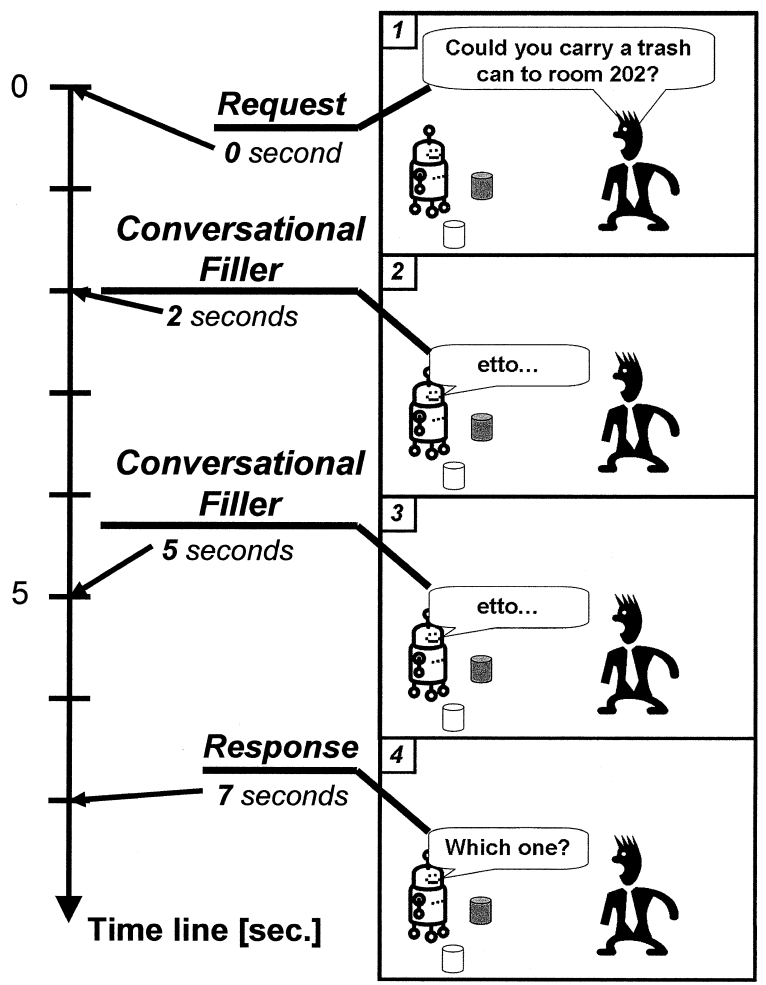

Fig. 9 Conversational fillers in Interaction with Robot Setting

無による影響を調べる。この間投詞の利用は，HRIにおける， 遅延に対する印象悪化の単純な抑制方法だと考える。 そこで, 参 考までに HCI の一般的な GUI 操作において, 遅延に対する印 象悪化の単純な抑制方法で，かつ間投詞と同等の役割があると 思われるマウスカーソルを砂時計にした場合の影響を調べる.

\section{1 実験方法}

\section{被験者}

実験 2 の被験者として, 実験 1 と同様の 38 名の大学生に協力 してもらった. また, なるべく実験 1 と同様の感覚で評価して もらうことを意図して, 実験 2 を実験 1 の後にすぐ行い, 被験 者に実験 1 の結果を踏まえて実験 2 の結果を評価してもらった.

\section{実験条件}

実験 2 では 4 (反応時間） $\times 2$ (間投詞の有無）の 8 条件で実 験を行った。それぞれの条件は下記のとおりである.

(a) 反応時間

研究所内のメンバを用いた予備実験の結果から，5秒までは 間投詞がなくとも耐えられそうだと予測を立てた。そこでこの 実験では， 3 秒， 5 秒， 7 秒，9 秒の四つの長い反応時間を用意 した。

\section{(b) 間投詞}

間投詞あり

間投詞ありの場合，ロボットは反応するまで「えっと」を 2 秒ごとに繰り返す (Fig. 9).「えっと」自体は発話に 1 秒かか るため, 反応時間 3 秒と 5 秒の場合は 1 回, 7 秒の場合は 2 回, 9 秒の場合は 3 回繰り返すことになる。なお,「えっと」も他の ロボットの発話同様, 事前に生成した合成音声をその都度再生 することにより実現した 
間投詞なし

間投詞なしの場合，ロボットは反応するまで何もしない.

実験手順

実験 2 は実験 1 同様, 被験者内比較を行い, 実験条件の順序 によって, 被験者の印象に偏りがでる可能性を除外するため, 実 験条件とタスクの順番に対し，カウンタバランスをとった.

実験 1 の手順と同様, 被験者はロボットとの対話を行った. 実験 1 同様，4 種の反応時間それぞれを 2 回ずつ, 8 セッショ ンを行った。 今回は反応時間以外に間投詞ありの場合と間投詞 なしの場合の二つの条件があるため，それぞれに対して 8 セッ ションずつ行った.

実験は被験者内比較を行ったため, 半分の被験者は間投詞あ りの条件下で 8 セッション行い, その後, 間投詞なしの条件下 で 8 セッション行った。残り半分の被験者は, 間投詞なしの条 件下で 8 セッション行った後, 間投詞ありの条件下で 8 セッショ ン行った.

\section{2 評価方法}

実験 2 の評価方法は実験 1 とまったく同様のものを用いた. 反応時間の評価には，ロボットの発話ごとに，その反応時間が 被験者にとってどうだったか, 7 段階（1 が最も悪く， 7 が最も 良い）のリッカート尺度で評価してもらった。

評価：ロボットが反応するタイミングに対する被験者の印象 (1. 非常に悪い 〜 . どちらでもない 7. 非常に良い)

被験者には，間投詞のタイミングを評価させないよう，間投 詞ではなく，ロボットの本当の反応に対して評価してもらうよ う教示した。

\section{3 仮説と予測}

ロボットの間投詞によって，ロボットが答えようとしている ことをユーザが知ることができるため，下記の仮説が成り立つ と考える.

（1）ロボットの間接詞の使用によって，ユーザの長い反応時間 に対する印象の悪化を抑えることができると考える.

また，この仮説に基づき，下記の予測を立てる.

（2）間投詞ありのほうが, 被験者の長い反応時間に対する印象 は，間投詞なしの場合に比べて同じ反応時間において高く なる。

\section{4 実験結果}

Fig. 10 に実験 2 のロボットとのインタラクションにおける 被験者の印象評価を示す.

\section{予測 1 の検証}

反応時間, 4 種の発話, 間投詞の有無を要因とし, 3 要因の分散 分析を行った. このうち, 反応時間 $(F(3,2363)=433.038, p<$ $0.001 ）$ と間投詞の有無 $(F(1,2363)=564.680, p<0.001)$ に主効果が確認されたが， 4 種の発話 $(F(3,2363)=1.928$, n.s.）に関しては主効果が確認できなかった。要因間の交互作 用としては，反応時間と間投詞の有無に有意傾向 $(F(3,2363)$ $=2.478, p<0.1)$ がみられた. 間投詞の有無に主効果がみら れたことで，間投詞ありの場合の反応時間に対する被験者の印 象が，間投詞なしの場合に比べてよいことが確かめられた.

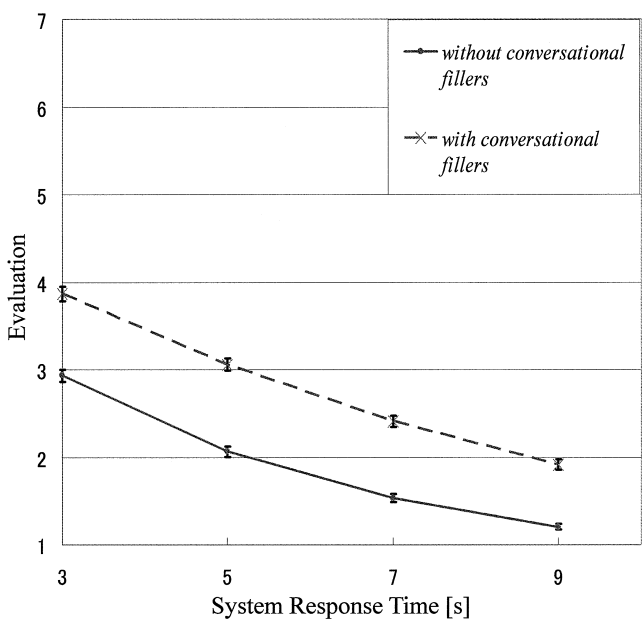

Fig. 10 SRT vs. impression of SRT (Robot)

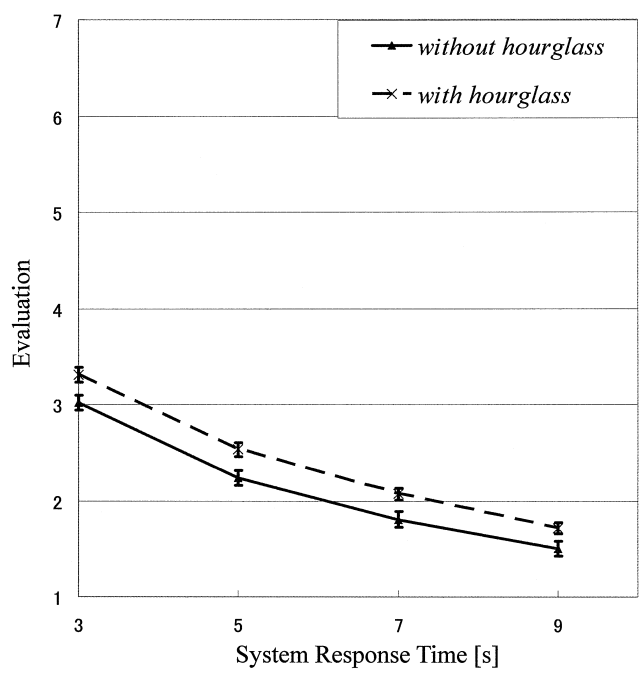

Fig. 11 SRT vs. impression of SRT (GUI)

\subsection{GUI 操作における砂時計の影響}

同様の実験を，実験 1 の GUI 操作の夕スクを用いて行った。 間投詞の代わりにカーソルを砂時計に変えることで，間投詞が あった場合と同程度の情報，システムが反応の準備をしている ことを被験者に知らせた。 その結果を Fig. 11 に示す.

反応時間, 4 種のボタン, 砂時計の有無を要因とし, 3 要因の 分散分析を行ったところ，反応時間 $(F(3,2363)=551.304$, $p<0.001)$ と砂時計の有無 $(F(1,2363)=92.195, p<0.001)$ に主効果が確認できたが，4種のボタン $(F(3,2363)=0.987$, n.s.）には主効果が確認できなかった。また, 要因間の交互作用 に有意差はみられなかった。

反応時間に対する被験者の印象悪化の抑制に砂時計の効果が 確認されたが，ロボットの間投詞の場合よりもその効果は相対 的に小さかった.

\section{4. 考察}

コンピュータに対する反応時間の場合と異なり，ロボットの 反応は何故少し遅いものが好まれるのか，間投詞の改良の余地， 
今回得られた知見の一般性の三つに関して考察を述べる.

\section{1 何故少し遅い反応が好まれるか}

実験 1 のロボットとのインタラクションにおいて, 被験者の 反応時間 1 秒に対する印象が 0 秒に対する印象よりも高かった ことから，ユーザは少し遅めの反応を好むことが確認された。 しかし，これは GUI 操作の場合にはみることができなかった。 これはユーザが，ロボットの外見や，指差しや音声による人間 に近いインタラクションなどの擬人的な特徽から，ロボットの 反応を人間のモデルを当てはめて予測していることに原因があ ると考えられる。人間同士の自然な会話では, 話すターンを交 互に交換し，その交換の際には一定の間が生じることが知られ ている [13]. 特に日本語の会話では, 0.6 秒が一般的な会話の自 然な間 $[14]$ ということが知られている。また，ユーザのロボッ トや GUI 等のシステムの反応時間に対する印象は, ユーザに よるそのシステムの反応の予測に大きく影響を受けていること が知られている [15]. この予測はユーザが想定したシステムの モデルに基づいており，モデル自体はユーザの過去の経験から 形成される。つまり, 実験で用いたような GUI の場合は, 家に 置いてあるパソコンなどユーザが過去に扱ったシステムがモデ ルの基になる。ロボットとのインタラクションにおいては，ロ ボットの反応のモデルを, その擬人的な特徵から人間同士の会 話を基に形成してしまうと考える，そのため，GUI 操作の場合 と反応時間に対する印象評価の傾向が異なってしまったと考え られる。 なお, 伊藤らの研究によれば, 間投詞として合成音声 を用いた場合, その品質の低さが問題となる可能性が示唆され ていた [8]. 今回用いた合成音声もそのイントネーションや話速 がやや不自然ではあったが，その質自体の向上のため，ユーザ がロボットとのインタラクションを人間同士の会話に擬するこ とに大きな障害にはならなかったと思われる。

\section{2 間投詞の改良}

実験 2 ではロボットとのインタラクションにおける，間投詞 の効果の検証を行った。 しかし今回使用した間投詞は最も単純 なもので，ロボットはただ「えっと」としか繰り返さない。間 投詞の, ユーザの反応時間に対する印象悪化を抑制させる効果 を高めるためには，たくさんの方法が存在する.

例えば，「えっと」と共に「あの」というのも間投詞の一種と なるが, 田窪の研究によれば, これら二つは心理的効果が異な る [9].「えっと」は話し手が発話の知識的な内容の生成時に用 いられ,「あの」は話し手が発話内容の表現形式の生成時に用い られるとしている。このことから, 間投詞を繰り返す際, 最初 は「えっと」を用いて，次に「あの」に切り替えると，そこに 思考の流れを感じることができる。これは GUIでいうならば, プロセスの進行具合をバーで表すのと似たような効果があると 考えられ，結果的にユーザの反応時間に対する印象悪化を抑制 させる効果を高めると推察される。

\section{3 一般性}

本研究はヒューマンロボットインタラクションにおけるロボッ トの反応時間に関する系統だった最初の研究の一つである。そ こでロボットの反応時間の特徵とロボットの間投詞の利用によ る効果に焦点を当てたが，ほかにもいろいろと研究の対象とな るものがある，それらがいまだに明らかにされていないため，今
回の知見もまだ活用の幅が狭い.しかし，人間がオペレータと してロボットを Wizard of $\mathrm{Oz}$ で操作する状況 [16] や，ロボッ 卜の発話生成を少し手助けする状況 [17] に対して, 今回得られ た知見から，少なくとも間投詞を活用できるのではないかと考 える。

ロボットの反応時間の印象評価はユーザのロボットの反応時 間の予測に依存するため, そのインタラクションの内容による ところが大きい，例えば一度にたくさんのことをロボットが行 う必要がある等, インタラクションが複雑であれば, ユーザは ロボットの反応時間を遅めに予測し， ロボットの反応時間が多 少遅くても辛抱強く待つのかもしれない. 実験では単純なイン タラクションのみを用いたため, 複雑なインタラクションにお いて，その効果はまだ検証されていない，今後，より多くの実 証実験を行うなかで検証していく必要がある.

今回, ロボットとのインタラクションの実験の参考として GUI 操作の実験を行った。ロボットとのインタラクションは発話に よる入力だが, GUI 操作ではマウスによる入力であり, 入力の モダリティが異なる．参考として音声入力によるシステムを用 いず，マウス入力によるGUI を用いたのは，ロボットを用いた 新しいインタラクションの形と, 従来のパソコン等の GUI を用 いた一般的なインタラクションの形を比べたかったからである. 発話を用いた，ロボットとのインタラクションに対して，マイ ナーである音声操作の GUI ではなく, 現在最も普及しているマ ウスやキーボード入力の GUI を比べることで， ロボットとの インタラクションが従来のインタラクションとどう異なるかに 注目した. 故に本研究は, 音声発話かマウス操作かという入力 のモダリティの違いや，ディスプレイ表示か発話やジェスチャ による擬人的な表現かという出力のモダリテイの違いに関して, 述べることはできない．

また本実験では, 被験者の発話内容を限定してしまう等, 口 ボットと人間の対話を制限し, 単純化してしまったために不自 然な部分があった。これは（1）ロボットの操作者が被験者の発 話を事前に知るために制限する必要があったことと，（2）何度 も実験を繰り返すため, 被験者が負担に感じない程度に単純化 する必要性があったからである。ユーザの発話内容を制限しな いと，あるいは別の知見が得られる可能性は捨てきれない．

また，実験には一つのロボットを用いたため，今回得られた 知見が適用できるのはある種のロボットに制限されるかもしれ ない.しかし複数のロボットそれぞれで試すことが難しい以上, これは仕方がないことである. 少なくともロボットが Robovie と同じような外見を持ち, 同じくらいの対話をこなすのであれ ば，今回の知見を用いることができると考える.

\section{5. 結論}

本研究は,コミュニケーションロボットの反応時間に焦点を 当てた.コミュニケーションロボットの反応時間に対する, ユー ザの印象を測定する実験を行い，コミュニケーションロボット の反応時間をデザインするための指針を示した，実験 1 では， 何秒後に反応すればよいのかに関するシステマティックな実験 を行い，応答時間と印象の関係を計測した，結果，ロボットが 0 秒で反応するより，1 秒反応を遅らせたほうがユーザに好まれ 
石黒浩萩田紀 博 安西祐一郎

るが, 反応するまでに 2 秒以上かかってしまうと GUI の反応同 様, 印象が悪化してしまうことが確かめられた。これは，GUI で有効な 2 秒ルールがコミュニケーションロボットのデザイン としても有用であることを示していると考えられる. 実験 2 で は, 間投詞の効果について, 実験 1 同様にシステマティックに計 測し，何秒後には印象がどの水準まで低下するかを明らかにし た. 結果, ロボットが短い時間内で反応できない場合, ロボッ トが間投詞を利用することで，ユーザの待つことに対する印象 悪化を抑制できることが確かめられた。

結論として，コミュニケーションロボットの開発に有用な，(1) ロボットの反応時間に対するユーザの印象は 1 秒以内であれば あまり変わらない, (2) 2 秒ルールが有効, （3）ロボットが反 応に 2 秒以上かかる場合, 間投詞の使用によりユーザの印象の 向上が可能という三つの知見が得られた.

謝 辞 本研究は, 総務省の研究委託により実施したものです.

\section{参 考 文 献}

[1] R.E. Barber and H.C. Lucas, Jr.: "System Response Time Operator Productivity, and Job Satisfaction," Communications of the ACM, vol.26, issue 11, pp.972-986, 1983.

[2] T. Goodman and R. Spence: "The Effect of System Response Time on Interactive Computer Aided Problem Solving," ACM SIGGRAPH Computer Graphics, Proc. Of the 5th Annual Conference on Computer Graphics and Interactive Techniques SIGGRAPH '78, vol.12, issue 3, pp.100-104, 1978.

[ 3 ] J.L. Guynes: "Impact of System Response Time on State Anxiety," Communications of the ACM, vol.31, no.3, pp.342-347, 1988.

[4] K. O'Hara and S.J. Payne: "Planning and the user interface: The effects of lockout time and error recovery cost," International Journal of Human-Computer Studies, vol.50, no.1, pp.41-59, 1999.

[5] R.B. Miller: "Response time in man-computer conversational transactions," Proc. Spring Joint Computer Conference,
AFIPS Press, Montvale, NJ, pp.267-277, 1968.

[6] T. Starner: "The Challenges of Wearable computing: Part 2," IEEE Micro, vol.21, issue 4, pp.54-67, 2001.

[ 7 ] B. Shneiderman: "Designing the User Interface," 3rd ed., Addison-Wesley, Reading, Mass., pp.358-367, 2001.

[8] 伊藤俊彦, 峯松信明, 中川聖一：“間投詞の働きの分析とシステム応答 生成における間投詞の利用と評価”, 日本音響学会誌, vol.55, no.5, pp.333-342, 1999.

[ 9 ] 田窪行則 : “2. 音声言語の言語学的モデルをめざして : 音声対話管理 標識を中心に (<解説 > 音声言語情報処理の現状と研究課題) ”, 情報 処理, vol.36, no.11, pp.1020-1026, 1995.

[10] T. Kanda, M. Kamasima, M. Imai, T. Ono, D. Sakamoto, H. Ishiguro and Y. Anzai: "A humanoid robot that pretends to listen to route guidance from a human," Autonomous Robots, vol.22, no.1, pp.87-100, 2007.

[11] M. Yamamoto and T. Watanabe: "Time Lag Effects of Utterance to Communicative Actions on CG Character-Human Greeting Interaction," Robot and Human Interactive Communication (ROMAN2006), pp.629-634, 2006.

[12] T. Kanda, H. Ishiguro, M. Imai and T. Ono: "Development and Evaluation of Interactive Humanoid Robots," Proc. Of the IEEE, vol.92, no.11, pp.1839-1850, 2004.

[13] H.H. Clark: Using language. Press Syndicate of the University of Cambridge, 1996.

[14] 長岡千賀, 小森政嗣, M.R. Draguna, 河瀬諭, 結城牧子, 片岡智嗣, 中村敏枝： “協調的対話における音声行動の 2 者間の一致一意見固持 型対話と聞き入れ型対話の比較—”, ヒューマンインタフェースシン ポジウム, pp.167-170, 2003.

[15] D.A. Norman: The Design of Everyday Things. Basic Books, 1988.

[16] A. Green, H. Höttenrauch and K.S. Eklundh: "Applying the Wizard-of-Oz Framework to Cooperative Service Discovery and Configuration," Proc. IEEE Int. Workshop on Robot and Human Interactive Communication, pp.575-580, 2004.

[17] S. Koizumi, T. Kanda, M. Shiomi, H. Ishiguro and N. Hagita: "Preliminary Field Trial for Teleoperated Communication Robots," Proc. IEEE Int. Workshop on Robot and Human Interactive Communication, pp.145-150, 2006. 


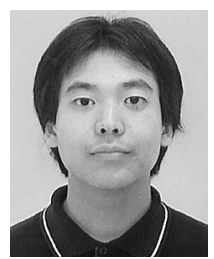

志和敏之（Toshiyuki Shiwa）

2006 年慶應義塾大学理工学部情報工学科卒業. 同 大学大学院開放環境科学専攻修士課程. 2007 年 6 月より ATR 知能ロボテイクス研究所の学外実習生 として勤務。

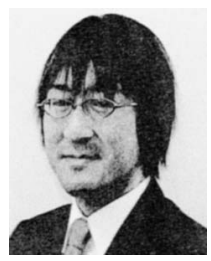

\section{今井倫太 (Michita Imai)}

1992 年慶應義塾大学理工学部電気工学科卒業. 1994 年同大学大学院計算機科学専攻修士課程修了. 同年, NTT ヒューマンインターフェース研究所入社. 1997 年よりATR 知能映像通信研究所研究員を経て, 現 在, 慶應義塾大学理工学部準教授, ATR 知能ロボ ティクス研究所客員研究員. 博士 (工学)。ロボッ トとの対話，センサを用いた状況知覚に興味をもつ

(日本ロボット学会正会員)

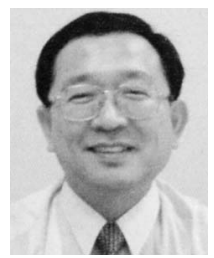

能学会各会員.
萩田紀博（Norihiro Hagita）

1978 年慶應義塾大学大学院工学研究科電気工学専 攻修士課程修了. 同年 日本電信電話公社 (現 NTT) 武蔵野電気通信研究所に入所. 文字認識や画像認識 などの研究に従事. NTT 基礎研究所などを経て, 現在 ATR 知能ロボティクス研究所所長. 工学博士. IEEE, 電子情報通信学会, 情報処理学会, 人工知 （日本ロボット学会正会員）

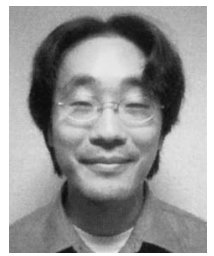

神田崇行 (Takayuki Kanda)

1998 年京都大学工学部情報工学科卒業. 2000 年同 大学大学院情報学研究科社会情報学専攻修士課程修 了. 2003 年同専攻博士課程修了. 博士 (情報学). 現在, ATR 知能ロボティクス研究所上級研究員. ヒューマンロボットインタラクション, 特にロボッ 卜の自律対話機構や社会的能力, 人間型ロボットの 身体を利用した対話に興味をもつ。

（日本ロボット学会正会員）

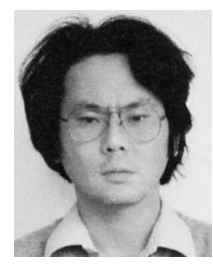

石黒 浩 (Hiroshi Ishiguro)

1991 年大阪大学大学院基礎工学研究科物理系専攻 博士課程修了. 工学博士. 同年山梨大学工学部情報 工学科助手, 1992 年大阪大学基礎工学部システム 工学科助手. 1994 年京都大学大学院情報学研究科 社会情報学専攻助教授. 2001 年, 和歌山大学システ ム工学部情報通信システム学科教授. 現在, 大阪大 学大学院工学研究科知能・機能創成工学専攻教授, ATR 知能ロボティ クス研究所第二研究室客員室長. 視覚移動ロボット, 能動視覚, パノ ラマ視覚, 分散視覚に興味をもつ. 人工知能学会, 電子情報通信学会, 情報処理学会, IEEE，AAAI 各会員。（日本ロボット学会正会員）

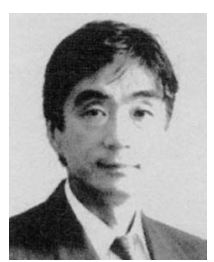

安西祐一郎 (Yuichiro Anzai)

1974 年慶應義塾大学大学院博士課程修了. 工学博 士. 慶應義塾大学工学部助手, 北海道大学文学部助 教授, 慶應義塾大学理工学部長を経て, 現在慶應義 塾長. 1981〜82 年カーネギーメロン大学客員助教 授. 計算機科学, 認識の情報処理過程の研究に従事. 著書に「認識と学習」(岩波書店),「知識と表象」(産 業図書), 「問題解決の心理学」(中央公論社),「脳科学の現在」(共著, 中央公論社),「認知科学ハンドブック」(共著, 共立出版) など. 訳書 に「心の社会」(ミンスキー, 産業図書)。（日本ロボット学会正会員） 